\title{
On the Optimal Indoor Air Conditions for SARS-CoV-2 Inactivation. An Enthalpy-Based Approach
}

\author{
Angelo Spena ${ }^{1}$, Leonardo Palombi ${ }^{2}$, Massimo Corcione ${ }^{3}\left[\begin{array}{l}\text {, } \\ \text {, Mariachiara Carestia }\end{array}{ }^{4}(\mathbb{D})\right.$ and \\ Vincenzo Andrea Spena ${ }^{3, *} *$ (D) \\ 1 Department of Enterprise Engineering, Tor Vergata University of Rome, 00133 Rome, Italy; \\ spena@uniroma2.it \\ 2 Department of Biomedicine and Prevention, Tor Vergata University of Rome, 00133 Rome, Italy; \\ palombi@uniroma2.it \\ 3 Department of Astronautical, Electrical and Energy Engineering, Sapienza University of Rome, \\ 00184 Rome, Italy; massimo.corcione@uniroma1.it \\ 4 Department of Industrial Engineering, Tor Vergata University of Rome, 00133 Rome, Italy; \\ mariachiara.carestia@uniroma2.it \\ * Correspondence: vincenzo.spena@uniroma1.it
}

Received: 9 July 2020; Accepted: 18 August 2020; Published: 21 August 2020

\begin{abstract}
In the CoViD-19 pandemic, the precautionary approach suggests that all possible measures should be established and implemented to avoid contagion, including through aerosols. For indoor spaces, the virulence of SARS-CoV-2 could be mitigated not only via air changes, but also by heating, ventilation, and air conditioning (HVAC) systems maintaining thermodynamic conditions possibly adverse to the virus. However, data available in literature on virus survival were never treated aiming to this. In fact, based on comparisons in terms of specific enthalpy, a domain of indoor comfort conditions between 50 and $60 \mathrm{~kJ} / \mathrm{kg}$ is found to comply with this objective, and an easy-to-use relationship for setting viable pairs of humidity and temperature using a proper HVAC plant is proposed. If confirmed via further investigations on this research path, these findings could open interesting scenarios on the use of indoor spaces during the pandemic.
\end{abstract}

Keywords: SARS-CoV-2; CoViD-19 pandemic; indoor air quality; specific enthalpy of moist air; HVAC systems setting

\section{Introduction}

The outbreak of the SARS-CoV-2 pandemic, having a huge impact on occupational and public health and safety, posed much concern on the spread of the virus in confined environments, especially in inhabited spaces. Although specific and effective therapies and vaccines are under development, other factors that can help to prevent the spread of the disease have to be considered, and proper mitigation measures need to be implemented. It has been recently inferred that good mechanical room ventilation using outdoor air would have an effect similar to a 50-60\% vaccination coverage in a poor ventilation scenario [1]. According to one of the first experimental studies available in literature on the SARS-CoV-2 virus, the stability of the virus in air and on surfaces is very similar to that of SARS-CoV-1 [2]. Therefore, SARS-CoV-2 viability in aerosol, depending on places, circumstances, and human factors, cannot be neglected [3-6]. Such a statement, unlike what has been stated in former studies [7], is true especially for indoor spaces, which leads to an assumption that the infectivity of the virus may be possibly reduced if indoor hygrothermal conditions hostile to the virion could be properly established using a suitable HVAC (heating, ventilation, and air conditioning) system [8]. Nonetheless, 
the pursuit of this objective must consider a number of other aspects: (i) the vulnerability of human mucous membranes tends to increase in decreasing relative humidity (RH) below 30\% [9]; (ii) the presence of humans inside indoor spaces for a long time (many hours) requires adequate, or at least bearable, comfort conditions [10]; (iii) to avoid the potential for mould and moisture threat, RH cannot exceed specific values (at most 80\%) in the coldest and least ventilated corners [11]; and (iv) to offset the risk of electrical static charge on electronic devices in office or healthcare environments, RH cannot be extremely low [12]. All of these statements highlight the need to identify a domain of RH and temperature values that could result in a decrease in the virus strength, being at the same time suitable for long-term human presence, building-structure preservation, and critical-devices operation [13]. Indeed, although dedicated HVAC systems can control indoor humidity and temperature, which can have direct effects on the transmission of infectious agents, a conclusive and unique recommendation is not yet available in literature [14-18], because existing studies have focussed on different objectives and have been conducted mostly using a solely virological approach [19-22]. The lacking facets of the research concern transmissibility not only via surfaces and fomites and aerosol droplets, but also, to a minor extent, via airborne particles, even though the latter could probably be more successfully inhibited than the former $[6,23,24]$. This study represents the first of an interdisciplinary approach to define the best environmental conditions that should be ensured by HVAC systems to oppose the spread of CoViD-19 in any indoor inhabited space. Despite the scarcity of available in-field studies to date, this study also enables us to infer some general considerations regarding this approach to viral spread prevention.

\section{Material and Methods}

\subsection{Background}

Viruses are among the smallest of the common primary biological aerosol particle (PBAP) classes, with physical diameters generally ranging from 20 to $250-400 \mathrm{~nm}$ [25]. They are commonly not airborne as individuals and are more likely to be attached to other suspended particles [26,27]. In the past two decades, new zoonotic coronaviruses have emerged, causing outbreaks in humans [28], i.e., SARS-CoV (2002, Betacoronavirus, subgenus Sarbecovirus) and MERS-CoV (2012, Betacoronavirus, subgenus Merbecovirus). In late 2019, a novel coronavirus related to a cluster of pneumonia cases in Wuhan, China (SARS-CoV-2), closely related to SARS-CoV and genetically clustered within the Betacoronavirus subgenus Sarbecovirus [29-31], was identified. SARS-CoV and MERS-CoV share relatively similar stability characteristics [32].

In the literature, the incidence of illness and infectivity of a virus transmitted via the airborne route in an indoor environment is acknowledged as a result of many factors [20,21]. These factors include humidity, particle size, temperature, population density, number of susceptible hosts, length of exposure, number of infected people producing contaminated aerosols, ventilation rate, infectious particle settling rate, whether the virus is enveloped or not, the presence of other aerosols or volatile organic compounds (VOC), exposure to UV light or to chemicals that inactivate or kill the virus, among others. Because nanometric particles carry the virus by forming wet droplet nuclei [33], virus aerosolisation in any confined space, mainly if the spread is from asymptomatic infected persons, may be dangerous via indirect transmission [3], including due to the resuspension of floor dust [34-36]. This nature of viruses reinforces the importance of avoiding crowded gatherings and implementing early identification and diagnosis of asymptomatic carriers for early quarantine or treatment [17].

Moreover, the concentration and infectivity of smaller airborne particles decrease more slowly, and thus their longer retention time in the air emphasises the concern that they pose. Both are applicable to SARS-CoV-2, which has a size in the order of $20 \mathrm{~nm}$. In 2010, Hanley and Borup stressed [37] that, in addition to intervention strategies including the use of masks and gloves, climate control of indoor locations should be considered by public health planners in developing recommendations to interrupt the spread of influenza. Accordingly, it should be remembered that the initial 187 cases of 
SARS-CoV-1 in the housing complex of Amoy Gardens in Hong Kong (2003) were related, with a reasonable degree of certainty, to bioaerosolisation [23]. Based on the consideration stated, a reasonable precautionary approach to the CoViD-19 pandemic is to be attempted, by all means, to prevent infections via aerosol [24].

\subsection{Literature Synopsis on Contributing Factors}

\subsubsection{Virus Survival and Transmission}

Relative Humidity RH-three mechanisms, even acting in a somewhat concerted manner, could explain the observed influence of RH on transmission [6]:

(i) $\mathrm{RH}$ may act at the level of the environment. Since a higher humidity implies a slower evaporation from large droplets, the faster evaporation occurring at low RHs would more rapidly change these into droplet nuclei ( $<5$ micron), quickly enough before they fall. Thus, people inhale fewer droplets at a higher $\mathrm{RH}$.

(ii) RH may act at the level of the host. The activity of nasal mucosa strongly depends on the humidity and temperature of the inhaled air, on the exposure time, and on the health of the individual [38]. Lower or higher $\mathrm{RH}$, compared to medium $\mathrm{RH}$ values, will alter the mucous viscosity and mucociliary activity. In general, extremely low humidities are reported as enabling the viruses' settlement in human hosts. Moreover, the dryness of the respiratory epithelium, which plays an important role via the evaporation of water from its surface (desiccation), may increase bacterial adherence and allows for greater penetration of foreign species, such as particles [39]. The upper airways need to achieve moisture neutrality and maximum mucociliary transport as fast as possible. However, the corresponding saccharin mucociliary clearance time in the upper airways is a function of RH [9]. This leads to a recommendation of $\mathrm{RH}>30 \%$ to avoid "dry eyes", and $\mathrm{RH}>10 \%$ to avoid nasal dryness.

(iii) RH may act at the level of the virus particle, affecting its virulence. Virus stability in air may directly affect virus transmission, because virus particles need to remain viable long enough after being expelled from the host to be taken up by a novel host (indirect transmission) [3].

Absolute Humidity (AH) - $\mathrm{RH}$ does not provide a fixed measure of water vapour content in air. Virus transmission responds to the amount of water vapour in the surrounding dry air, i.e., $\mathrm{AH}$, and not how close that air is to saturation, i.e., RH [20]. Many studies have shown that the survival and transmission potentials of influenza viruses in wintertime are inversely associated with AH rather than with $\mathrm{RH}$ [22,40-43], and that low temperature and low $\mathrm{AH}$, as opposed to higher temperature and humidity, prevents the disruption of the influenza virus $[44,45]$. Indeed, lipid-containing viruses are generally more stable in aerosols and are more labile in moist air than in dry air [46,47], although the presence of proteins can alter this relationship [48].

Temperature- the role of temperature appears to be more complex, but relatively less heavy than those other factors. It was suggested that under the conditions of high humidity, the fluidity of lipid-containing envelope is stabilised at low temperature, thereby protecting the virion [49]. Cold temperatures and low RH conditions favour the survival and transmission of certain influenza virus [50,51], and are associated with an increased occurrence of respiratory tract infections.

Concentration of salts $(\mathrm{pH})$-as salts become more concentrated as water is lost through evaporation [4], it has been hypothesised that RH can affect the viability of enveloped viruses by altering the $\mathrm{pH}$ in the aerosols [14], which, in turn, induces conformational changes to the viral glycoproteins and damages to viral infectivity [3]. Viability decreases in saline solutions, but does not change significantly in solutions supplemented by proteins, and increases dramatically in mucous $[6,15]$. 


\subsubsection{Indoor Environment Vulnerabilities}

Domestic comfort and work performance-indoor air quality (IAQ) is often perceived as more acceptable at low RH and low temperature [10,52], depending on alterations not only of the VOC emission profile, but also of dynamics, composition, deposition and resuspension of inhaled particles. However, this contrasts the outcome of many studies that show that elevated RH may reduce complaint rates, and supports eye tear-film stability and physiology (as already mentioned) and osmolarity of the upper airways, thus enhancing work performance in offices. Furthermore, laboratory experiments reveal a greater resuspension of large particles and lower resuspension of smaller particles at low RH $[18,36]$. As a reference, the ASHRAE (American Society of Heating, Refrigerating and Air-conditioning Engineers) recommended comfort zone for domestic and office-like environments [13] is highlighted in Figure 1, in which the psychrometric chart of moist air at atmospheric pressure is displayed.

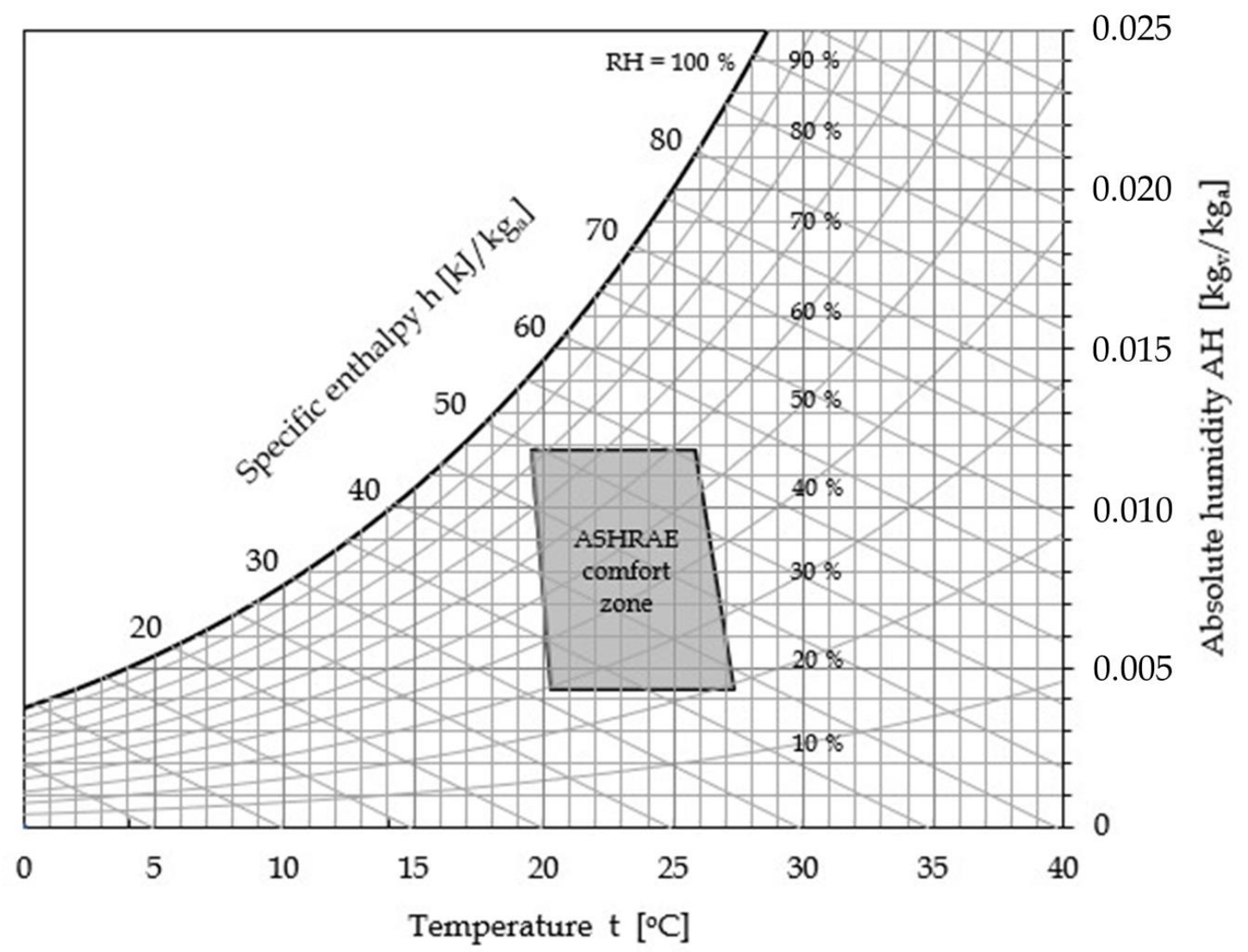

Figure 1. Conventional domestic and office-like comfort zone based on ASHRAE [13].

Building salubrity and equipment safety—when building materials or furnishings are damp for a consistent time period, mould and bacteria often colonise the materials, and can produce microscopic airborne particles in the indoor air [53,54], some containing allergens or chemicals with the potential to induce inflammation in the respiratory system [6]. Typical isopleths of mould germination and growth rates reported in Figure 2 show that the wetter is a surface, the quicker mould spores will germinate and grow $[55,56]$. Typical room temperatures of $21-22{ }^{\circ} \mathrm{C}$ are ideal for mould growth. Whilst WHO recommends an indoor $\mathrm{RH}$ not higher than $45 \%$ to inhibit the growth of mites [11], according to Figure 2 a reasonable limit that balance conflicting requirements appears to be $80 \%$. Furthermore, electric or electronic devices consistently require higher humidities to reduce electrical static charge, which may otherwise occur in medical test and therapy equipment, as well in computer areas, control halls and data centres. 


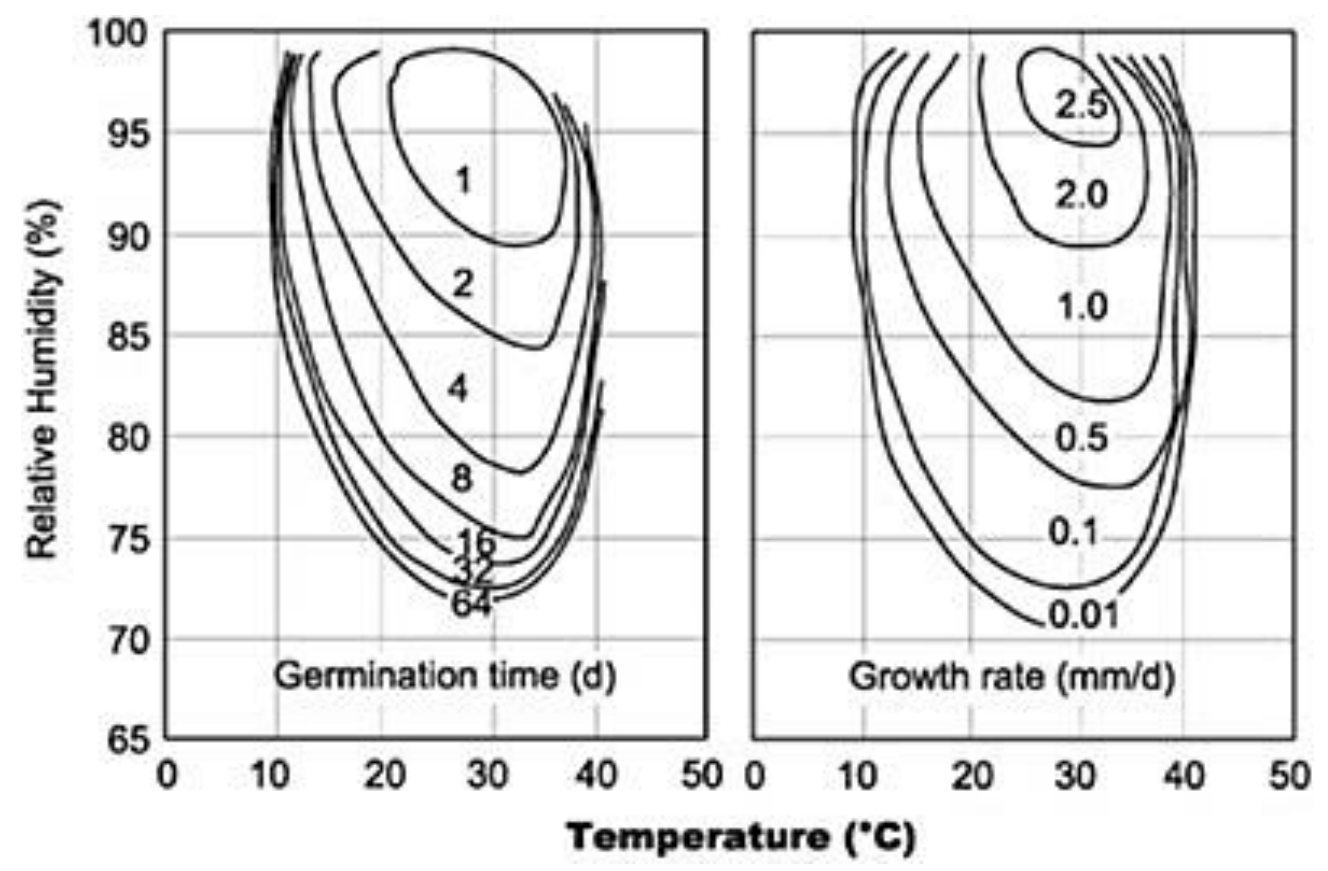

Figure 2. Mould germination and growth rate as a function of $t$ and relative humidity (RH) [56].

Hospital epidemiology and HVAC setting-nosocomial transmission has been widely described as an important driver in the epidemiology of SARS and MERS [57]. A notable feature of the SARS disease was its predilection for transmission in the health care setting and to close family and social contacts. During the outbreak of SARS-CoV-1 in Guangzhou, clinicians kept the windows of patient rooms open and well ventilated and this was thought to have reduced virus survival, thereby reducing nosocomial transmission [19]. Healthcare workers treating influenza patients are particularly prone to infection because they can be exposed to aerosolised viruses from multiple patients in closed clinical environments during the flu seasons [58]. This led to the ASHRAE recommendation of identifying cohorting possibilities for pandemic situations for whole areas of a hospital to be placed under isolation and negative pressure [6]. In fact, negative pressure ventilation and high air exchange rate were effective in minimising airborne SARS-CoV-2 inside the intensive care unit (ICU), coronary care unit (CCU) and ward rooms of Renmin Hospital, where sub-micron aerosols containing the virus were hypothesised to come from the resuspension of virus-laden aerosols from staff apparel because of its higher mobility [59].

\subsection{Challenging Trade-Off}

In outdoor open spaces, social distancing can be considered a good prescription for preventing viral infections. However, for confined indoor environments, whose dimensions limit both the distance between the people and the dilution of the virus concentration, social distancing seems less applicable and effective [60], and thus a different approach is required. The progress in implementing clean, even aseptic, confined spaces shows the level of capability that environmental engineering has reached throughout the past decades; indeed, today it is possible to set, control and maintain a number of environmental parameters in confined and crowded spaces in industrial, residential and transportation applications by means of proper HVAC equipment [61,62]. There are two possible ways of achieving this result. One is quantitative, i.e., at the source level, based on the dilution of the infectious agent load via air changes [63-65], their capture through devices such as ultra-low particulate air (ULPA) filters or electrostatic precipitators (ESPs) [12], or the use of UV radiation [6]. The other is qualitative, i.e., at the ambient level, reachable through the surrounding of the infectious agents with adverse thermodynamic conditions. The present paper expressly deals with only the second action, though without any prejudice to the concurring use of some or all the other quantitative actions. As discussed earlier, 
the infectious mechanisms are far from being fully understood, thus generalisations are not applicable, and solutions should be dealt with on a nearly virus-by-virus basis $[8,48]$. This could be due not only to the inadequacy or scarcity of the available experimental studies, or to the overall complexity of the phenomena as reported in literature $[14,20,66]$, but also probably to intrinsic differences in the families of influenza and $\mathrm{CoV}$ viruses, and mainly to the lack of a holistic approach by the researchers. In fact, cold and dry conditioned air in office-like environments appears to favour survival and transmission of certain airborne viruses, but not of others $[48,67,68]$. Moreover, when selecting indoor temperature and humidity levels, the aforementioned concurrent aspects need to be balanced, in relation to both human comfort and to building salubrity and equipment operation $[66,69,70]$, provided that a proper HVAC system, rather than mere split air-conditioners, or similar, with no air renewals [62], are available.

\subsection{A Parameter for Correlating Literature Data}

The experimental data available on aerosolised coronavirus survival are very few and widely scattered throughout the temperature-humidity phase space, which indicates that their analyses cannot lead to any definitive result, yet it may delineate a path for future investigation on SARS-CoV-2. Only four studies containing useful information pertaining to this topic have been readily found in open literature, which allowed us to evaluate the viability of $\mathrm{CoV}$ virus after aerosolisation and put it in direct relationship with the environmental conditions. The available data report survival rate over time in terms of either Plaque Forming Units (PFU) or Median Tissue Culture Infectious Dose $\left(\mathrm{TCID}_{50}\right)$, whose values can be put in relation to each other, provided that given assumptions on the cellular line used and the titration protocols are verified [71]. However, for the purpose of the present study, in order to compare the survival data from different sources expressed with different units, we evaluated the survival rate reduction over time $(1 \mathrm{~h})$ for different $\mathrm{RH}$ and temperature parameters, by introducing a parameter called Viral Load Survival, denoted as VLS ${ }_{1 \mathrm{~h}}$, with the general meaning of "percentage of detected levels of virus survival after one hour from spread" and calculated as the ratio between the viral load after one hour and that at the moment of its diffusion, regardless of the method used by the different research teams to determine the infectious titre of the virus, i.e., PFU or TCID 50 .

First of all, the results reported by Prussin et al. [72], who investigated the survival of the enveloped bacteriophage Phi6, have been considered as a reference. In fact, Phi6 can be treated as a reliable surrogate of CoV-1 coronaviruses in the estimation of their survival, see Adcock et al. [73] and Turgeon et al. [74]. Phi6 survival after $1 \mathrm{~h}$ has been investigated both in the form of droplets and aerosol, with respect to $\mathrm{RH}$ at a temperature of $22{ }^{\circ} \mathrm{C}$, resulting in a correlation coefficient of 0.98 and no significant difference between the two distributions ( $p$-value $=0.095$ ). The collected data, expressed as relative infectious ratio, i.e., the ratio of the concentration of PFU derived from exposed samples to the concentration of PFU in the control sample, pointed out the existence of a remarkable minimum for $\mathrm{VLS}_{1 \mathrm{~h}}$ of nearly $1 \%$ at $75 \% \mathrm{RH}$. Notice that a significant decrease in infectivity at mid-range RHs was reported also in previous investigations looking at coronaviruses' survival on surfaces, such as, for example, the study carried out by Casanova et al. [75].

Subsequently, the data available from the papers published by van Doremalen et al. [76], and Pyankov et al. [77], have been considered. Both research groups analysed the aerosol stability of human betacoronavirus EMC (isolate $\mathrm{HCoV-EMC/2012)} \mathrm{assumed} \mathrm{as} \mathrm{representative} \mathrm{of}$ MERS-CoV-1, reporting the time-distributions of $\mathrm{TCID}_{50}$ as a function of $\mathrm{RH}$ and temperature. Van Doremalen et al. [76] reported also the aerosol stability of $\mathrm{H}_{1} \mathrm{~N}_{1}$ (A/Mexico/4108/2009).

From the first study, values of $\mathrm{VLS}_{1 \mathrm{~h}}$ of $93 \%$ at $20{ }^{\circ} \mathrm{C}$ and $40 \% \mathrm{RH}$, and of $11 \%$ at $20{ }^{\circ} \mathrm{C}$ and $70 \%$ $\mathrm{RH}$, can be extracted. From the second study, values of $\mathrm{VLS}_{1 \mathrm{~h}}$ of approximately $63 \%$ at $25^{\circ} \mathrm{C}$ and $79 \% \mathrm{RH}$, and of $4.7 \%$ at $38{ }^{\circ} \mathrm{C}$ and $24 \% \mathrm{RH}$, can be determined. The latter value can be determined to be susceptible to an increase from $4.7 \%$ to about $25 \%$, owing to a potential underestimation, which can be easily deduced from an attentive inspection of the time-trend displayed for the airborne virus concentration, compared with the expected exponential decay extrapolated using all the virus concentrations measured in the first $30 \mathrm{~min}$. Additionally, a couple of datasets extracted from a recent 
investigation conducted by van Doremalen et al. [2] at $22 \pm 1{ }^{\circ} \mathrm{C}$ and $65 \% \mathrm{RH}$ using both SARS-CoV-1 and SARS-CoV-2, have also been counted. According to the reported time distributions of TCID 50 , virus survivals of nearly $29 \%$ and $30 \%$ can be estimated for SARS-CoV-1 and SARS-CoV-2, respectively.

Notice that only Pyankov et al. [77] declared tolerances in thermoigrometric measurements, namely $\pm 0.5{ }^{\circ} \mathrm{C}$ in temperature and $\pm 2 \%$ in RH. According to Noti [58], data were generally considered significant if $p$-value $<0.05$.

\section{Results}

To correlate all the collected data (see Table 1), for each thermodynamic state of equilibrium identified by its temperature and relative humidity, the specific enthalpy of moist air $h$ has been calculated as follows [78]:

$$
h=c_{a} t+A H\left(c_{v} t+r\right)
$$

with

$$
\mathrm{AH}=0.623\left[(\mathrm{RH} \% / 100) \mathrm{p}_{\mathrm{s}}(\mathrm{t})\right] /\left[\mathrm{p}-(\mathrm{RH} \% / 100) \mathrm{p}_{\mathrm{s}}(\mathrm{t})\right]
$$

where $c_{\mathrm{a}}$ and $\mathrm{c}_{\mathrm{v}}$ are the specific heats at constant pressure of dry air and water vapour, which, around ambient temperature, can be assumed as equal to $1.006 \mathrm{~kJ} / \mathrm{kg}{ }^{\circ} \mathrm{C}$ and $1.86 \mathrm{~kJ} / \mathrm{kg}^{\circ} \mathrm{C}$, respectively; $\mathrm{t}$ is the temperature in degrees centigrade; $\mathrm{AH}$ is the absolute humidity of moist air, in $\mathrm{kg} / \mathrm{kg}_{\mathrm{dry}}$-air, also called humidity ratio and defined as the ratio of the mass of water vapour to the mass of dry air in the moist air sample; $r$ is the latent heat of vapourisation of water at its triple point, equal to $2501 \mathrm{~kJ} / \mathrm{kg} ; \mathrm{p}_{\mathrm{s}}(\mathrm{t})$ is the saturated vapour pressure of water at temperature $t$ in Pascal, and $p$ is the total pressure of moist air, typically the atmospheric pressure, in Pascal.

The saturated vapour pressure of water in Pascal can be calculated from the empirical formula derived by Hyland and Wexler for the temperature range of 0 to $200{ }^{\circ} \mathrm{C}[78,79]$ :

$$
\ln p_{s}(T)=C_{1} / T+C_{2}+C_{3} T+C_{4} T^{2}+C_{5} T^{3}+C_{6} \ln T
$$

in which $\mathrm{C}_{1}=-5.8002206 \times 10^{3}, \mathrm{C}_{2}=1.3914493 \times 10^{0}, \mathrm{C}_{3}=-4.8640239 \times 10^{-2}, \mathrm{C}_{4}=4.1764768 \times 10^{-5}$, $\mathrm{C}_{5}=-14452093 \times 10^{-8}, \mathrm{C}_{6}=6.5459673 \times 10^{0}$, whereas $\mathrm{T}$ is the absolute temperature in Kelvin degrees,

\begin{tabular}{|c|c|c|c|c|c|c|}
\hline & $\begin{array}{c}\text { Temperature } \\
{\left[{ }^{\circ} \mathrm{C}\right]}\end{array}$ & $\begin{array}{l}\text { RH } \\
(\%)\end{array}$ & $\mathrm{VLS}_{1 \mathrm{~h}}$ & Virus Type & $\begin{array}{c}\mathrm{AH} \\
{\left[\mathrm{kg}_{\text {vap }} / \mathrm{kg}_{\text {dry-air }}\right]}\end{array}$ & $\begin{array}{c}\mathrm{H} \\
{\left[\mathrm{kJ} / \mathrm{kg}_{\text {dry-air }}\right]}\end{array}$ \\
\hline Pyankov et al. [77]-2018 & 25 & 79 & 0.634 & HCoV-EMC & 0.0158 & 65.32 \\
\hline Van Doremalen et al. [2]-2020 & 22 & 65 & 0.300 & SARS-CoV-2 & 0.0107 & 49.44 \\
\hline Van Doremalen et al. [2]-2020 & 22 & 65 & 0.293 & SARS-CoV-1 & 0.0107 & 49.44 \\
\hline Van Doremalen et al. [76]-2013 & 20 & 40 & 0.930 & HCoV-EMC & 0.0058 & 34.84 \\
\hline Prussin et al. [72]-2018 & 22 & 33 & 0.970 & Phi6 & 0.0054 & 35.88 \\
\hline Prussin et al. [72]-2018 & 22 & 43 & 0.820 & Phi6 & 0.0071 & 40.09 \\
\hline Prussin et al. [72]-2018 & 22 & 55 & 0.360 & Phi6 & 0.0091 & 45.18 \\
\hline Prussin et al. [72]-2018 & 22 & 75 & 0.010 & Phi6 & 0.0124 & 53.72 \\
\hline Prussin et al. [72]-2018 & 22 & 85 & 0.050 & Phi6 & 0.0141 & 58.03 \\
\hline
\end{tabular}
$\mathrm{T}=\mathrm{t}+273.15$.

Table 1. Virus survival obtained from literature experimental data and related information.

The distributions of the Viral Load Survival $\mathrm{VLS}_{1 \mathrm{~h}}$ of the viruses plotted against the specific enthalpy of moist air are reported in Figure 3, in which the interpolation curve of the reference data of Phi6 bacteriophage is also depicted. It is apparent that the data available for MERS-CoV-1, SARS-CoV-1 and SARS-CoV-2 viruses are substantially well distributed along the curve representative of the behaviour of Phi6 bacteriophage. In this connection, it is worth noticing that, should the survival reported by Pyankov and co-workers for the $\mathrm{HCoV}-\mathrm{EMC}$ virus at $38{ }^{\circ} \mathrm{C}$ and $24 \% \mathrm{RH}$ be increased 
from $4.7 \%$ to $25 \%$, as discussed earlier, the data for these two sets of conditions would be closer to the interpolation curve. Furthermore, it seems meaningful that for environmental conditions whose specific enthalpy of moist air falls within the range between 50 and $60 \mathrm{~kJ} / \mathrm{kg}$-dry air, the survival of all the considered viruses sinks dramatically. This also seems to be in line with recent observations reported regarding the temperature and humidity weather-data recorded along the path going from East to West of the significant spread of CoViD-19 caused by SARS-CoV-2 [80].

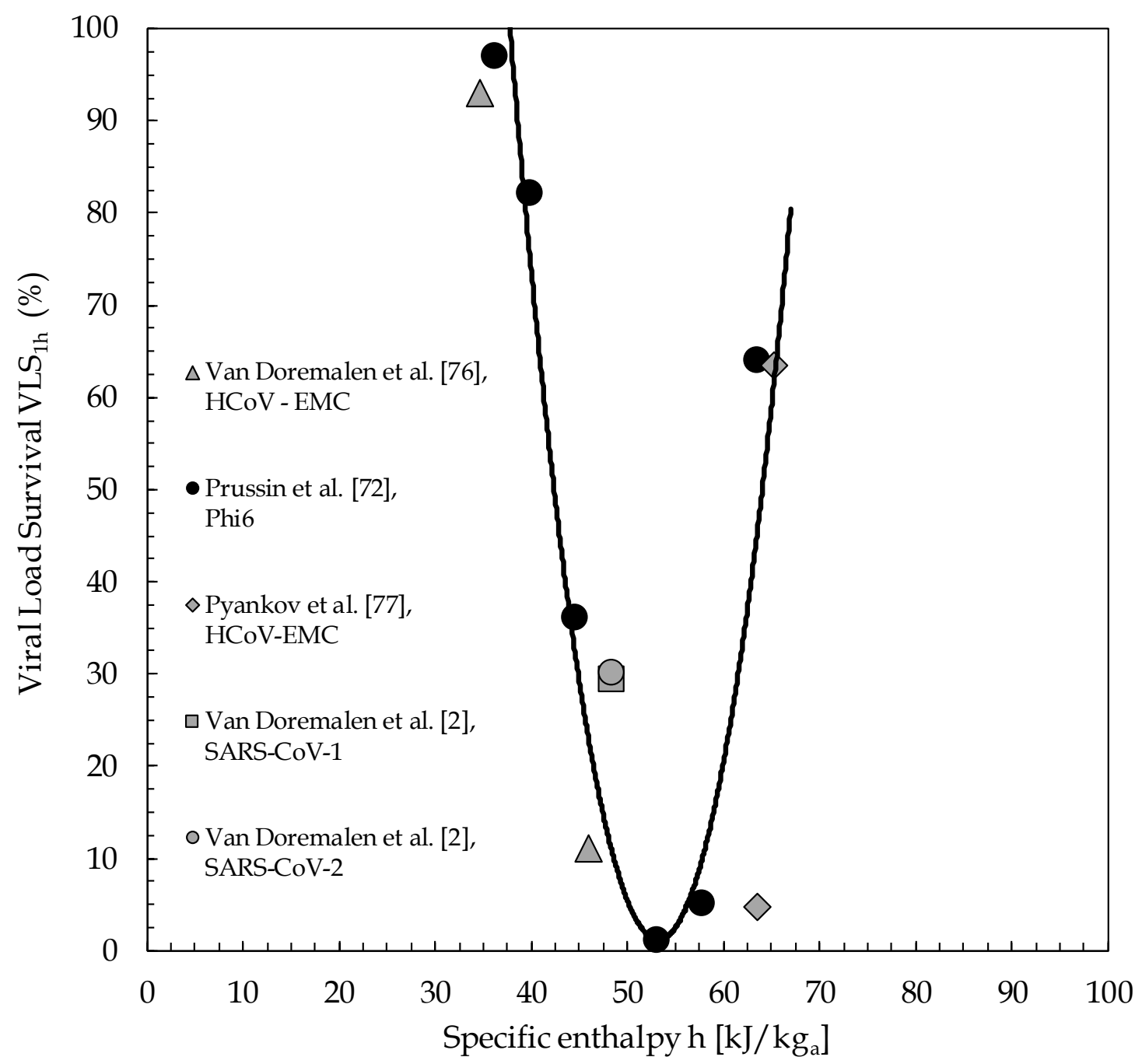

Figure 3. Viral load survival (VLS) $1 \mathrm{~h}$ as a function of specific enthalpy h of moist air (kJ/kg-dry air).

\section{Discussion}

\subsection{Obtained Space of Viable Solutions_Preliminary Recommendations}

As a matter of data reliability, errors come from either titration (as $\left.\operatorname{TCID}_{50}\right)[2,47,48]$ or infectivity estimation (as PFU) [34], and from temperature and RH recordings, information about the latter being almost lacking in any study cited earlier. However, if we assume an error of $\pm 0.25^{\circ} \mathrm{C}$ for the measured temperature, and of $\pm 5.0 \% \mathrm{RH}$ for the measured $\mathrm{RH}$ as realistic for an actual room environment, the consequent uncertainty for the calculated specific enthalpy $\mathrm{h}$ of moist air would remain in the order of a few percent, slightly raising from $\pm 4.0 \%$ at $20{ }^{\circ} \mathrm{C}$ to $\pm 4.7 \%$ at $25^{\circ} \mathrm{C}$. This enables us to infer that the proposed interpolation curve portrayed in Figure 3 well complies with the uncertainties intrinsic with the collected data. Notice that no direct correlation has been found to hold between VLS 1 h and either air temperature $\mathrm{t}$ or relative humidity $\mathrm{RH} \%$ or absolute humidity $\mathrm{AH}$ independently of one 
another, yet a clear relationship seems to exist between $\mathrm{VLS}_{1 \mathrm{~h}}$ and the thermodynamic potential specific enthalpy $h$ of moist air, the minimum of which should correspond to optimal pairs of temperature and relative humidity values for coronavirus viral load inactivation, wherein SARS-CoV-2 infectivity actually appears to be nearly suppressed. Even if the recent SARS-CoV-2 could evolve in the future, the literature data show that if the specific enthalpy $h$ of moist air is kept in the range between 50 and $60 \mathrm{~kJ} / \mathrm{kg}$-dry air, the virus infectivity appears to be nearly offset. Additionally, as discussed earlier, the relative humidity $\mathrm{RH}$ should be maintained neither lower than $30 \%$, for fitness and safety reasons, nor higher than $80 \%$, for mould germination reasons.

The intersection of the region including all the thermodynamic states of moist air such that the specific enthalpy lies in the range $50-60 \mathrm{~kJ} / \mathrm{kg}$-dry air and the relative humidity ranges between $30 \%$ and $80 \%$ with the ASHRAE recommended comfort zone for domestic and office-like environments, coloured in dark grey in the psychrometric chart depicted in Figure 4, identifies the space of viable solutions, i.e., the set of indoor environmental conditions able to satisfy both requirements of SARS-CoV-2 inactivation and hygrothermal comfort of resident people.

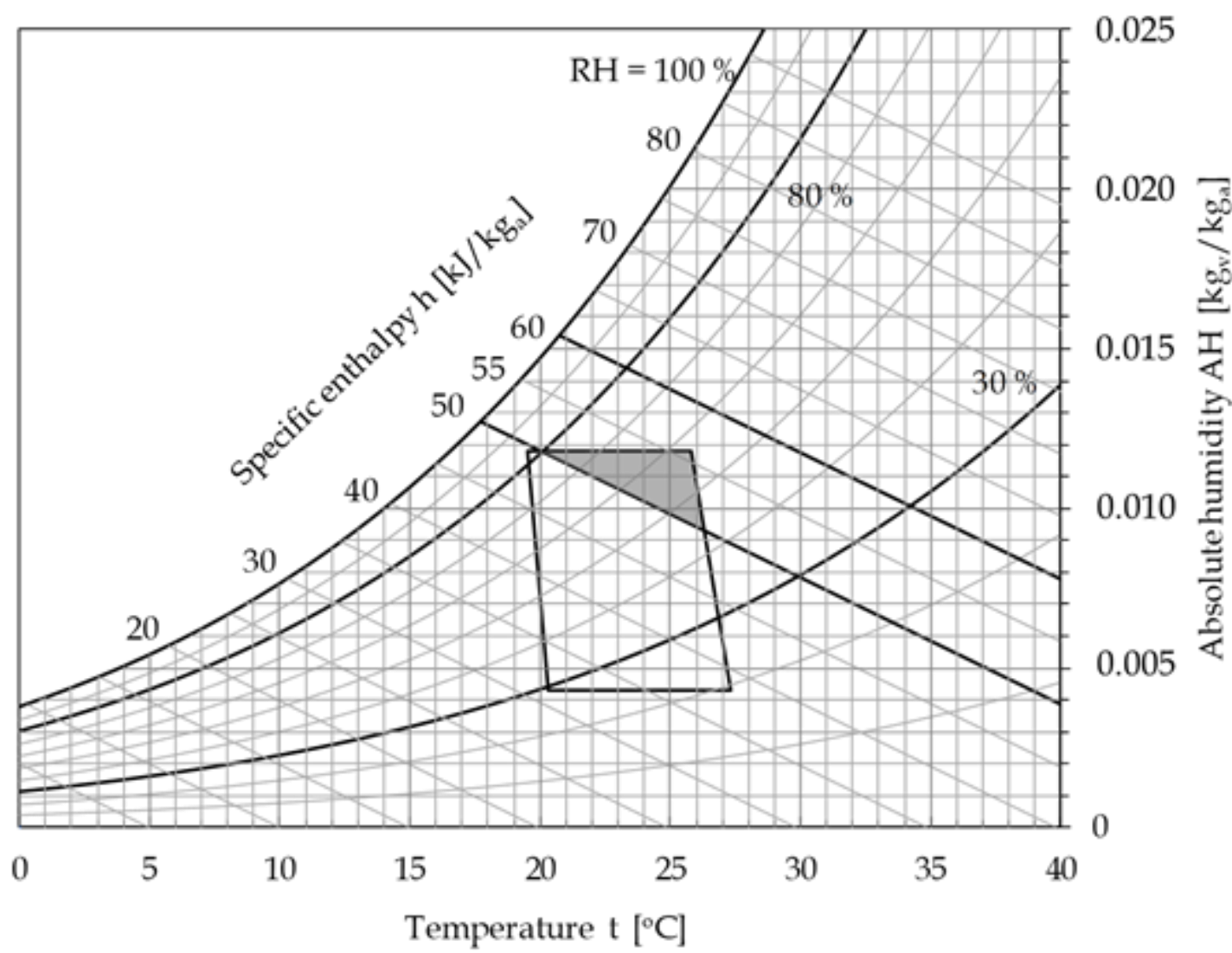

Figure 4. Optimal thermodynamic conditions of moist air to be ensured in indoor spaces to reduce the exposure risk.

Notice that the obtained relationship between the parameter $\mathrm{VLS}_{1 \mathrm{~h}}$ and the specific enthalpy of moist air should be strictly applied within the temperature range of investigation, which spans from 20 to $25{ }^{\circ} \mathrm{C}$, as discussed earlier. This, however, as shown in Figure 4, does not represent a true limit of applicability, because - quantitatively — the lower boundary temperature of the ASHRAE recommended comfort zone does practically coincide with $20{ }^{\circ} \mathrm{C}$, while its upper limit does not significantly exceed $25^{\circ} \mathrm{C}$; but also-qualitatively—the observed tendency (a decreasing RH at an increasing temperature) fits well with the usual comfort requirements.

As a preliminary recommendation, we can conclude that the optimum thermodynamic conditions at which moist air should be maintained to reduce the exposure risk in indoor spaces are those confined 
within the intersection region located in the upper right end of the standard ASHRAE comfort zone. This means that the typical summertime design conditions of $25-26^{\circ} \mathrm{C}$ with a $50 \% \mathrm{RH}$ are located within this region, although very close to its lower boundary, whereas those typical of wintertime, i.e., $20{ }^{\circ} \mathrm{C}$ with a $50 \% \mathrm{RH}$, lie outside it. Accordingly, it would be advisable that $\mathrm{AH}$ of supply air is kept slightly higher than usual, thus implying a larger humidification in winter and a smaller dehumidification in summer, which result in an increase in the heating costs in winter and a decrease in the cooling costs in summer. Moreover, the indoor temperature in winter should be kept some degrees higher than usual, with further additional heating costs.

\subsection{HVAC Plants Optimal Setting}

For any assigned value $h$ of the specific enthalpy of moist air, the relationship existing between relative humidity $\mathrm{RH} \%$ and temperature $\mathrm{t}$ can be obtained by replacing Equation (2) into Equation (1), which, after some algebra, gives $\mathrm{r}=2501 \mathrm{~kJ} / \mathrm{kg}$, where, as said, $\mathrm{c}_{\mathrm{a}}$ and $\mathrm{c}_{\mathrm{v}}$ can be assumed as equal to $1.006 \mathrm{~kJ} / \mathrm{kg}{ }^{\circ} \mathrm{C}$ and $1.86 \mathrm{~kJ} / \mathrm{kg}{ }^{\circ} \mathrm{C}$, respectively.

$$
\mathrm{RH} \%=100\left[\mathrm{p} / \mathrm{p}_{\mathrm{s}}(\mathrm{t})\right] /\left[1+0.623\left(\mathrm{c}_{\mathrm{v}} \mathrm{t}+\mathrm{r}\right) /\left(\mathrm{h}-\mathrm{c}_{\mathrm{a}} \mathrm{t}\right)\right]
$$

This means that, when imposing the optimal value $h=55 \mathrm{~kJ} / \mathrm{kg}$-dry air (or any other value of $\mathrm{h}$ included in the range between 50 and $60 \mathrm{~kJ} / \mathrm{kg}$-dry air), the value of the relative humidity corresponding to an assigned value of the air temperature can be calculated through Equation (4), which leads to identifying the optimal indoor environmental conditions for SARS-CoV-2 inactivation.

As a ready-to-use tool, Figure 5 allows the determination, for an assigned value of the specific enthalpy of moist air $h$, of the pairs of suitable values of $t$ and $\mathrm{RH}$ to be established to reduce the exposure risk inside indoor spaces, directly obtained by way of Equation (4).

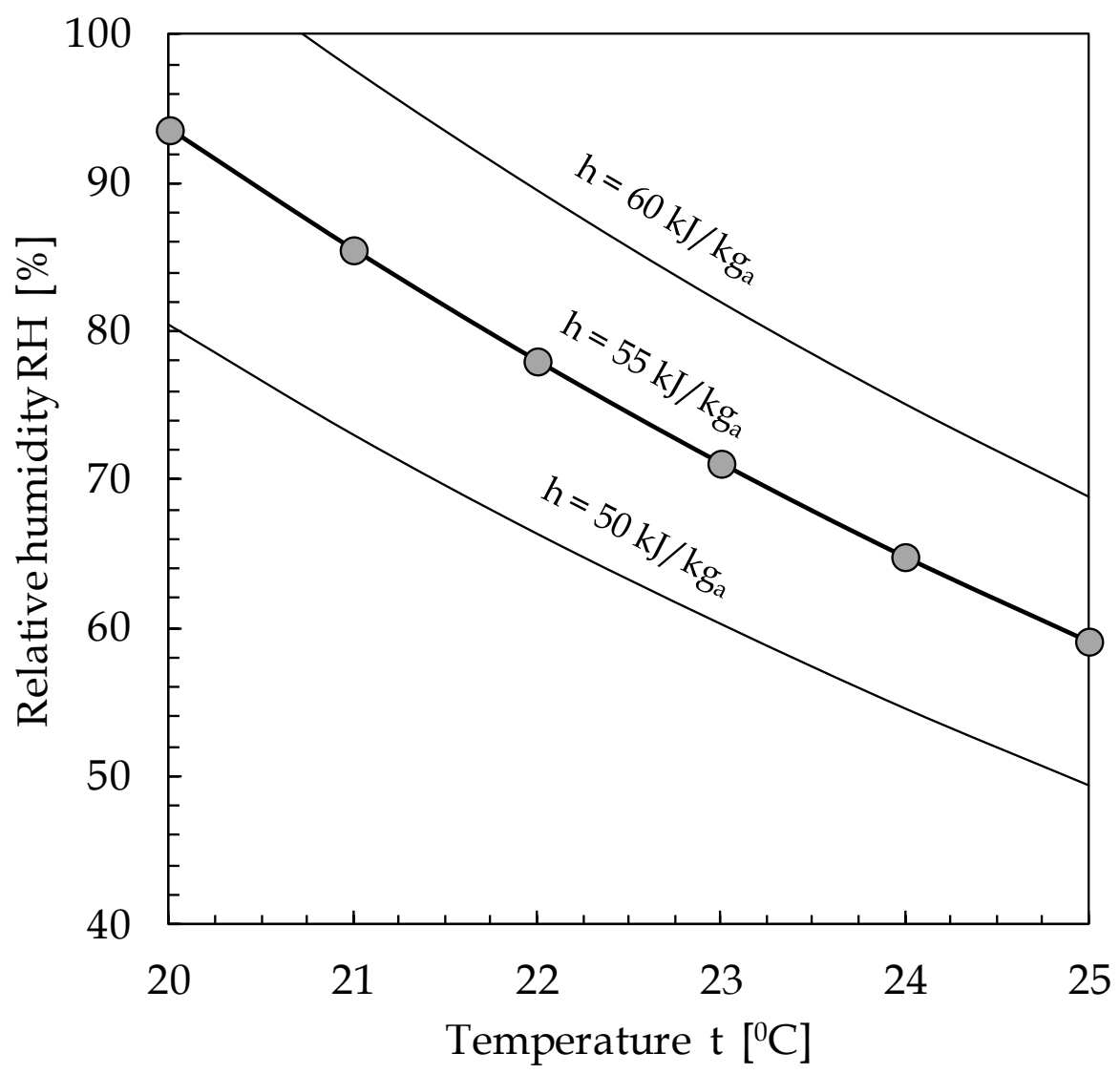

Figure 5. Indoor environmental optimal pairs of $\mathrm{t}$ and $\mathrm{RH}$ for coronaviruses viral load inactivation. 


\section{Conclusions}

The obtained results confirm that, in general, temperature or humidity cannot be independently correlated with coronaviruses viability, because a one-to-one approach reveals an intrinsically erratic nature. Simultaneously, our results infer a relationship between coronaviruses survival and the thermodynamic potential specific enthalpy of moist air, exhibiting a minimum value for the proposed parameter $\mathrm{VLS}_{1 \mathrm{~h}}$ at around $55 \mathrm{~kJ} / \mathrm{kg}$-dry air. This appears to unlock the previously acknowledged impasse on research method, thereby opening a broad perspective considering straightforward applications.

We pointed out that a space of viable solutions does exist, representing the set of indoor environmental conditions able to satisfy both requirements of SARS-CoV-2 inactivation and hygrothermal comfort of resident people. This can be easily summarised by the enforcement of a specific enthalpy around $55 \mathrm{~kJ} / \mathrm{kg}$-dry air. To further analyse this value, an easy-to-use diagram for determining the optimal pairs of air temperature and relative humidity is proposed. As a matter of fact, the combinations of air temperature and relative humidity optimal for virus inactivation fall not far from those typical for human comfort. Furthermore, conditions preventing extremely low values of $\mathrm{RH}$ for sanitary cautions like eyes dryness, and for not too high values of $\mathrm{RH}$ for avoidance of mould risks and evapo-transpiration discomfort, appear not to significantly reduce the space of viable solutions.

If our results should be corroborated by further experiments, possibly extended to air temperatures higher than $25^{\circ} \mathrm{C}$ and slightly lower than $20^{\circ} \mathrm{C}$, the previously discussed exposed enforcement by means of suited HVAC plant could yield an important in-field support to the prevention and control of CoViD-19 transmission, particularly in the case of recurrence of the disease.

The outlined interdisciplinary methodology can be extended to any health-strategic approach. From an epidemiological point of view, deeper insights could explore and explain the reasons that cause the observed narrow interval of specific enthalpy h of moist air to be critical, whose nature of state property involving overall heat (sensible + latent) seems to suggest some kind of thermodynamical "resonance", or a melt of crucial factors. More specifically, as regarding the envelope of the virus, a topic to investigate could be specific enthalpy values in the range between 3.9 and $5.1 \mathrm{~kJ} / \mathrm{g}$ of water vapour, seeking possible cross-linking reactions occurring between the surface proteins of the virus, or certain crystallisation of the virus at the point of efflorescence. Another topic to be addressed could be the mechanism by which salts affect coronaviruses viability at a molecular level, or how the presence of proteins can alter this relationship, searching for singularities in the infectious mechanism of SARS-CoV-2.

This research did not receive any specific grant from funding agencies in the public, commercial, or not-for-profit sectors.

Author Contributions: Conceptualization, A.S. and V.A.S.; Data curation, A.S., M.C. (Massimo Corcione) and M.C. (Mariachiara Carestia); Formal analysis, V.A.S.; Investigation, A.S., L.P., M.C. (Massimo Corcione) and V.A.S.; Methodology, A.S., L.P., M.C. (Massimo Corcione) and V.A.S.; Supervision, A.S., L.P. and M.C. (Massimo Corcione); Validation, A.S., L.P., M.C. (Massimo Corcione) and V.A.S.; Visualization, M.C. (Massimo Corcione) and V.A.S.; Writing-original draft, A.S., L.P., M.C. (Massimo Corcione) and V.A.S.; Writing-review \& editing, A.S., L.P., M.C. (Massimo Corcione), M.C. (Mariachiara Carestia) and V.A.S. All authors have read and agreed to the published version of the manuscript.

Funding: This research received no external funding.

Conflicts of Interest: The authors declare no conflict of interest.

\section{References}

1. Smieszek, T.; Lazzari, G.; Salathé, M. Assessing the dynamics and control of droplet and aerosol-transmitted influenza using an indoor positioning system. Nat. Sci. Rep. 2019, 9, 2185. [CrossRef] [PubMed]

2. Van Doremalen, N.; Bushmaker, T.; Morris, D.H.; Holbrook, M.G.; Gamble, A.; Williamson, B.N.; Tamin, A.; Harcourt, J.L.; Thornburg, N.J.; Gerber, S.I.; et al. Aerosol and Surface Stability of SARS-CoV-2 as Compared with SARS-CoV-1. N. Engl. J. Med. 2020, 382, 1564-1567. [CrossRef] [PubMed] 
3. Cai, J.; Sun, W.; Huang, J.; Gamber, M.; Wu, J.; He, G. Indirect virus transmission in cluster of Covid-19 cases, Wenzhou, China. Emerg. Infectuos Dis. 2020, in press. [CrossRef] [PubMed]

4. Stadnytskyi, V.; Bax, C.E.; Bax, A.; Anfinrud, P. The Airbourne Lifetime of Small Speech Droplets and Their Potential Importance in SARS-CoV-2 Trasmission. Available online: https://www.pnas.org/cqi/doi/10.1073/ pnas.2006874117 (accessed on 25 May 2020).

5. Somsen, G.A.; van Rijn, C.; Kooij, S.; Bem, R.A.; Bonn, D. Small droplet aerosols in poorly ventilated spaces and SARS-CoV-2 transmission. Lancet Respir. Med. 2020, in press. [CrossRef]

6. American Society of Heating Refrigerating Air Conditioning Engineers, ASHRAE Position Document on Airborne Infectious Diseases. Available online: https://www.ashrae.org/file\%20library/about/position\% 20documents/airborne-infectious-diseases.pdf (accessed on 5 April 2020).

7. World Health Organization. Report of the WHO-China Joint Mission on Coronavirus Disease 2019. Available online: https://www.who.int/docs/default-source/coronaviruse/who-china-joint-mission-on-covid-19-finalreport.pdf (accessed on 5 April 2020).

8. Weber, T.P.; Stilianakis, N.I. Inactivation of influenza a viruses in the environment and models of transmission. J. Infect. 2008, 57, 361-373. [CrossRef]

9. Sunwoo, Y.; Chou, C.; Takeshita, J.; Murakami, M. Physiological and subjective responses to low relative humidity. J. Physiol. Anthropol. 2006, 25, 7-14. [CrossRef]

10. Fang, L.; Wyon, D.P.; Clausen, G.; Fanger, P.O. Impact of indoor air temperature and humidity in an office on perceived air quality, SBS symptoms and performance. Indoor Air 2004, 14, 74-81. [CrossRef]

11. World Health Organization. WHO Guidelines for Indoor Air Quality—Dampness and Mould. Available online: http://www.euro.who.int/_data/assets/pdf_file/0017/43325/E92645.pdf?ua=1 (accessed on 28 March 2020).

12. Kettleson, E.M.; Ramaswami, B.; Hogan, C.J., Jr.; Lee, M.H.; Statyukha, G.A.; Biswas, P.; Angenent, L.T. Airborne virus capture and inactivation by an Electrostatic Particle Collector. Environ. Sci. Technol. 2009, 43, 5940-5946. [CrossRef]

13. American Society of Heating. Refrigerating and Air-Conditioning Engineers: ANSI/ASHRAE Standard 62.1-2019 - Ventilation for acceptable Indoor Air Quality; ASHRAE: Atlanta, GA, USA, 2019.

14. Yang, W.; Marr, L. Mechanisms by which ambient humidity may affect viruses in aerosols. Appl. Environ. Microbiol. 2012, 78, 6781-6788. [CrossRef]

15. Yang, W.; Elankumuran, S.; Marr, L.C. Relationship between humidity and influenza A viability in droplets and implications for influenza's seasonality. PLOS ONE 2012, 7, e46789. [CrossRef]

16. Kormuth, K.A.; Lin, K.; Prussin, A.J.; Vejerano, E.P.; Tiwari, A.J.; Cox, S.S.; Myerburg, M.M.; Lakdawala, S.S.; Marr, L.C. Influenza virus infectivity is retained in aerosol and droplets independent on Relative Humidity. J. Infect. Dis. 2018, 218, 739-747. [CrossRef] [PubMed]

17. Lowen, A.C.; Mubareka, S.; Steel, J.; Palese, P. Influenza virus transmission is dependent on Relative Humidity and temperature. PLoS Pathog. 2007, 3, e151. [CrossRef] [PubMed]

18. Han, Y.L.; Hu, Y.M.; Qian, F.P. Effects of air temperature and humidity on particle deposition. Chem. Eng. Res. Des. 2011, 89, 2063-2069. [CrossRef]

19. Chan, K.H.; Peiris, J.S.M.; Lam, S.Y.; Poon, L.L.M.; Yuen, K.Y.; Seto, W.H. The effects of temperature and relative humidity on the viability of the SARS coronavirus. Adv. Virol. 2011, 2011, 734690. [CrossRef]

20. Memarzadeh, F. Literature review of the effect of temperature and humidity on viruses. Ashrae Trans. 2012, 118, 1049-1060.

21. Schaffer, F.L.; Soergel, M.E.; Straube, D.C. Survival of airborne influenza virus: Effects of propagating host, relative humidity, and composition of spray fluids. Arch. Virol. 1976, 51, 263-273. [CrossRef]

22. Metz, J.A.; Finn, A. Influenza and humidity-Why a bit more damp may be good for you! J. Infect. 2015, 71, 554-558. [CrossRef]

23. Yu, I.T.; Li, Y.; Wong, T.W.; Tam, W.; Chan, A.T.; Lee, J.H.; Leung, D.Y.; Ho, T. Evidence of airborne transmission of the SARS. N. Engl. J. Med. 2004, 350, 1731-1739. [CrossRef]

24. Allen, J.G. Your building can make you sick or keep you well. N. Y. Times 2020, 98, 1095-1096.

25. Donsgheng, D. From the smallest virus to the biggest gene: Marching towards gene therapy for duchenne muscular dystrophy. Discov. Med. 2006, 33, 103-108.

26. International Committee on Taxonomy of Viruses, ICTV 9th Report 2011. Available online: https://talk.ictvonline.org/ictv-reports/ictv_9th_report/positive-sense-rna-viruses-2011/w/posrna_ viruses/223/coronaviridae-figures (accessed on 28 March 2020). 
27. Cox, C.S. Airborne bacteria and viruses. Sci. Prog. 1989, 73, 469-499. [PubMed]

28. Yin, Y.; Wunderink, R.G. MERS, SARS and other coronaviruses as causes of pneumonia. Respirology 2018, 23, 130-137. [CrossRef] [PubMed]

29. Wuhan City Health Committee, Wuhan Municipal Health Committee's Report on Unexplained Viral Pneumonia 2020. Available online: http://wjw.wuhan.gov.cn/front/web/showDetail/2020010509020 (accessed on 15 March 2020).

30. World Health Organization. WHO Statement Regarding Cluster of Pneumonia Cases in Wuhan, China. Available online: https://www.who.int/china/news/detail/09-01-2020-who-statement-regarding-cluster-ofpneumonia-cases-in-wuhan-china (accessed on 4 April 2020).

31. Liu, Y.; Ning, Z.; Chen, Y.; Guo, M.; Liu, Y.; Gali, N.K.; Sun, L.; Duan, Y.; Cai, J.; Westerdahl, D.; et al. Aerodynamic characteristics and RNA Concentration of SARS-CoV-2 aerosol in Wuhan hospitals during CoViD-19 outbreak. Biorxiv Prepr. 2020. [CrossRef]

32. World Health Organization. Novel Coronavirus-China. Geneva 2020. Available online: https://www.who. int/csr/don/12-january-2020-novel-coronavirus-china/en/ (accessed on 4 April 2020).

33. Setti, L.; Passarini, F.; Gennaro, G.A.; Palmisani, J.; Buono, P. Relazione circa l'effetto dell'inquinamento da particolato atmosferico e la diffusione di virus nella popolazione. Position Pap. 2020. SIMA, Università degli Studi di Bari. Available online: https:/www.simaonlus.it/wpsima/wp-content/uploads/2020/ 03/COVID19_Position-Paper_Relazione-circa-1\%E2\%80\%99effetto-dell\%E2\%80\%99inquinamento-daparticolato-atmosferico-e-la-diffusione-di-virus-nella-popolazione.pdf (accessed on 5 May 2020).

34. Khare, P.; Marr, L.C. Simulation of vertical concentration gradient of influenza viruses in dust resuspended by walking. Indoor Air 2015, 25, 428-440. [CrossRef] [PubMed]

35. Qian, J.; Ferro, A.R. Resuspension of dust particles in a chamber and associated environmental factors. Aerosol Sci. Technol. 2008, 42, 566-578. [CrossRef]

36. Qian, J.; Peccia, J.; Ferro, A.R. Walking-induced particle resuspension in indoor environments. Atmos. Environ. 2014, 89, 464-481. [CrossRef]

37. Hanley, B.P.; Borup, B. Aerosol influenza transmission risk contours: A study of humid tropics versus winter temperate zone. Virol. J. 2010, 7, 98. [CrossRef]

38. Cruz, A.A.; Togias, A. Upper airway reactions to cold air. Curr. Allergy Asthma Rep. 2008, 8, $111-117$. [CrossRef]

39. Naclerio, R.M.; Pinto, J.; Assanasen, P.; Baroody, F.M. Observations on the ability of the nose to warm and humidify inspired air. Rhinology 2007, 45, 102-111.

40. Shaman, J.; Kohn, M. Absolute humidity modulates influenza survival, transmission, and seasonality. Proc. Natl. Acad. Sci. USA 2009, 106, 3243-3248. [CrossRef] [PubMed]

41. Shaman, J.; Pitzer, V.E.; Viboud, C.; Grenfell, B.T.; Lipsitch, M. Absolute humidity and the seasonal onset of influenza in the continental United States. PLoS Biol. 2010, 8, e1000316. [CrossRef]

42. Jaakkola, K.; Saukkoriipi, A.; Jokelainen, J.; Juvonen, R.; Kauppila, J.; Vainio, O.; Ziegler, T.; Rönkkö, E.; Jaakkola, J.J.K.; Ikäheimo, T.M. Decline in temperature and humidity increases the occurrence of influenza in cold climate. Environ. Health 2014, 13, 22. [CrossRef] [PubMed]

43. Lipsitch, M.; Viboud, C. Influenza seasonality: Lifting the fog. Proc. Natl. Acad. Sci. USA 2009, 106, 3645-3646. [CrossRef]

44. Koep, T.H.; Enders, F.T.; Pierret, C.; Ekker, S.C.; Krageschmidt, D.; Neff, K.L.; Lipsitch, M.; Shaman, J.; Huskins, W.C. Predictors of indoor absolute humidity and estimated effects on influenza virus survival in grade schools. BMC Infect. Dis. 2013, 13, 71. [CrossRef]

45. UUd-Dean, S.M.M. Structural explanation for the effect of humidity on persistence of airborne virus: Seasonality of influenza. J. Theoret. Biol. 2010, 264, 822-829. [CrossRef]

46. Akers, T.G. Some aspects of the airborne inactivation of viruses. In Airborne Transmission and Airborne Infection; Hers, J.F.P., Winkler, K.C., Eds.; John Wiley \& Sons: New York, NY, USA, 1973.

47. DeJong, J.C. Decay Mechanism of Polio and EMC Viruses in Aerosols. In Proceedings of the Third International Symposium on Aerobiology; Silver, I.H., Ed.; Academic Press: New York, NY, USA, 1970.

48. Morawska, L. Droplet fate in indoor environments, or can we prevent the spread of infection? Indoor Air 2006, 16, 335-347. [CrossRef]

49. Ijaz, M.K.; Brunner, A.H.; Sattar, S.A.; Nair, R.C.; Johnson-Lussenburg, C.M. Survival characteristics of airborne human Coronavirus 229E. J. Gen. Virol. 1985, 66, 2743-2748. [CrossRef] 
50. Ikäheimo, T.M.; Jaakkola, K.; Jokelainen, J.; Saukkoriipi, A.; Roivainen, M.; Juvonen, R.; Vainio, O.; Jaakkola, J.J. A decrease in temperature and humidity precedes human rhinovirus infections in a cold climate. Viruses 2016, 8, E244. [CrossRef]

51. Davis, R.E.; Dougherty, E.; McArthur, C. Cold, dry air is associated with influenza and pneumonia mortality in Auckland, New Zealand. Influenza Other Respir. Viruses 2016, 10, 310-313. [CrossRef]

52. Fang, L.; Clausen, G.; Fanger, P.O. Impact of temperature and humidity on the perception of indoor air quality. Indoor Air 1998, 8, 80-90. [CrossRef]

53. Fang, L.; Clausen, G.; Fanger, P.O. Impact of temperature and humidity on chemical and sensory emissions from building materials. Indoor Air 1999, 9, 193-201. [CrossRef] [PubMed]

54. Fechter, J.O.; Englund, F.; Lundin, A. Association between temperature, relative humidity and concentration of volatile organic compounds from wooden furniture in a model room. Wood Mater. Sci. Eng. 2006, 1, 69-75. [CrossRef]

55. Dampness and Mold. Indoor Air Quality Scientific Findings Resource Bank. Available online: https: //iaqscience.lbl.gov/dampness-summary (accessed on 5 May 2020).

56. Morse, R. Indoor Air Quality and Mold Prevention of the Building Envelope, WBDG. 2017. Available online: https://www.wbdg.org/resources/indoor-air-quality-and-mold-prevention-building-envelope (accessed on 5 May 2020).

57. European Centre for Disease Prevention and Control. 2020. Factsheet for Health Professionals on Coronaviruses. Available online: https://www.ecdc.europa.eu/en/facts (accessed on 5 May 2020).

58. Noti, J.D.; Blachere, F.M.; McMillen, C.M.; Lindsley, W.G.; Kashon, M.L.; Slaughter, D.R.; Beezhold, D.H. High humidity leads to loss of infectious influenza virus from simulated coughs. PLoS ONE 2013, 8, e57485. [CrossRef]

59. Blachere, F.M.; Lindsley, W.G.; Pearce, T.A.; Anderson, S.E.; Fisher, M.; Khakoo, R.; Meade, B.J.; Lander, O.; Davis, S.; Thewlis, R.E.; et al. Measurement of airborne influenza in a hospital emergency department. Clin. Infect. Dis. 2009, 48, 438-440. [CrossRef]

60. Spena, A. Air Change Ratio Indoor \& CoViD-19-Cambiate L'aria. 18 March 2020. Available online: http://astrolabio.amicidellaterra.it/node/2064 (accessed on 5 May 2020).

61. Spena, A. Efficienza Energetica. Governare la Complessità Delle Opzioni più Avanzate; La Termotecnica: Milan, Italy, 2017; pp. 7-8.

62. Spena, A. Efficienza energetica e igiene degli ambienti chiusi: What is past, is prologue. Nuova Energ. 2020, 2, 49-53.

63. Janssen, J.E. Ventilation for acceptable indoor air quality. ASHRAE J. 1989, 31, 40-48.

64. Seppänen, O.; Fisk, W.J.; Lei, Q.H. Ventilation and performance in office work. Indoor Air 2006, 16, $28-36$. [CrossRef]

65. Mazzenga, C.; Iaria, V.; Spena, V.A. On the misleading perception by the occupants of the indoor air renewals. First experimental evidences in densely occupied lecture halls. In Proceedings of The 51st AICARR International Conference on The Human Dimension of Building Energy Performance, Venice, Italy, 20-22 February 2019.

66. Wolkoff, P. Indoor Air Humidity, Air Quality, and Health. Int. J. Hyg. Environ. Health 2018, 221, 376-390. [CrossRef]

67. Tang, J.W. The effect of environmental parameters on the survival of airborne infectious agents. J. $R$. Soc. Interface 2009, 6, 737-746. [CrossRef]

68. Teller, R. Aerosol transmission of influenza a virus: A review of new studies. J. R. Soc. Med. 2009, 6, 783-790. [CrossRef] [PubMed]

69. Wolkoff, P. External eye symptoms in indoor environments. Indoor Air 2017, 27, 246-260. [CrossRef] [PubMed]

70. Handbook-Fundamentals AS. American Society of Heating Refrigerating Air Conditioning Engineers; ANSI/ASHRAE Standard 55-2013; Thermal Environmental Conditions for Human Occupancy, ASHRAE: Atlanta, GA, USA, 2013.

71. Wulff, N.H.; Tzatzaris, M.; Young, P.J. Monte Carlo simulation of the Spearman-Kaerber TCID50. J. Clin. Bioinform. 2012, 2, 1-5. [CrossRef] [PubMed] 
72. Prussin, A.J.; Schwake, D.O.; Lin, K.; Gallagher, D.L.; Buttling, L.; Marr, L.C. Survival of the enveloped virus Phi6 in droplets as a function of relative humidity, absolute humidity, and temperature. Appl. Environ. Microbiol. 2018, 84. [CrossRef]

73. Adcock, N.J.; Rice, E.W.; Sivaganesan, M.; Brown, J.D.; Stallknecht, D.E.; Swayne, D.E. The use of bacteriophages of the family Cystoviridae as surrogates for $\mathrm{H} 5 \mathrm{~N} 1 \mathrm{highly}$ pathogenic avian influenza viruses in persistence and inactivation studies. J. Environ. Sci. Health 2009, 44, 1362-1366. [CrossRef]

74. Turgeon, N.; Toulouse, M.J.; Martel, B.; Moineau, S.; Duchaine, C. Comparison of five bacteriophages as models for viral aerosol studies. Appl. Environ. Microbiol. 2014, 80, 4242-4250. [CrossRef]

75. Casanova, L.M.; Jeon, S.; Rutala, W.A.; Weber, D.J.; Sobsey, M.D. Effects of air temperature and relative humidity on coronavirus survival on surfaces. Appl. Environ. Microbiol. 2010, 76, 2712-2717. [CrossRef]

76. Van Doremalen, N.; Bushmaker, T.; Munster, V.J. Stability of Middle East respiratory syndrome coronavirus (MERS-CoV) under different environmental conditions. Eurosurveillance 2013, 18, 20590. [CrossRef]

77. Pyankov, O.V.; Bodnev, A.S.; Pyankova, O.G.; Agranovski, I.E. Survival of aerosolized coronavirus in the ambient air. J. Aerosol Sci. 2018, 115, 158-163. [CrossRef]

78. ASHRAE Handbook of Fundamentals. In Ch. 6-Psychrometrics; American Society of Heating, Refrigeration and Air-Conditioning Engineers: Atlanta, GA, USA, 2005.

79. Hyland, R.W.; Wexler, A. Formulations for the Thermodynamic Properties of the Saturated Phases of $\mathrm{H}_{2} \mathrm{O}$ from 173.15 K to 473.15 K; ASHRAE Transactions: San Diego, CA, USA, 1983; Volume 89, pp. 500-519.

80. Sajadi, M.M.; Habibzadeh, P.; Vintzileos, A.; Shokouhi, S.; Miralles-Wilhelm, F.; Amoroso, A. Temperature, humidity, and latitude analysis to predict potential spread and seasonality for COVID-19. SSRN Electron. J. 2020. [CrossRef]

(C) 2020 by the authors. Licensee MDPI, Basel, Switzerland. This article is an open access article distributed under the terms and conditions of the Creative Commons Attribution (CC BY) license (http://creativecommons.org/licenses/by/4.0/). 